\title{
Adoption of Technologies in Sugarcane - A Performance Analysis
}

\author{
Jitendra Kumar Chauhan $^{1 *}$, T. Rajula Shanthy ${ }^{2}$ and Senthamil ${ }^{3}$ \\ ${ }^{1}$ Agriculture Extension, College of Post Graduate Studies in \\ Agricultural Sciences, Umiam, Meghalya, CAU, Imphal, Manipur, India \\ ${ }^{2}$ Agriculture Extension, ICAR-SBI, Coimbatore, Tamil Nadu \\ ${ }^{3}$ DODL, TNAU, Coimbatore, India \\ *Corresponding author
}

\section{A B S T R A C T}

\begin{tabular}{|l|}
\hline Key w o r d s \\
Sugarcane, \\
Adoption of \\
technologies, \\
Advantages, \\
Constraint analysis, \\
Suggestions \\
\hline Article Info \\
\hline $\begin{array}{l}\text { Accepted: } \\
\text { 12 December } 2020 \\
\text { Available Online: } \\
\text { 10 January } 2021\end{array}$ \\
\hline
\end{tabular}

Keywords

Sugarcane,

Adoption of

Constraint analysis,

\section{Introduction}

India is an agrarian country with varied agroclimatic conditions suited for growing diverse crops. Sugarcane is an important crop in the country, economically and sociologically. It is the second largest agro-industry next to textiles (Panghal, 2010).

In Tamil Nadu, area under sugarcane has declined due to continuous drought, and
The present investigation was carried out to analyze the socio-economic status of the sugarcane growers, to know their level of adoption of varied sugarcane technologies, perception of advantages related with the technologies in sugarcane, and to identify the constraints in adoption by interviewing 60 growers from the command area of Madras Sugars, Tamil Nadu. It was found that farmers had varied levels of adoption of sugarcane technologies. All the respondent farmers adopted new sugarcane varieties, thorough land preparation with cultivator, ridges and furrows making followed by basal application of organic manures and top dressing with nitrogen and potash fertilizers. The constraints encountered by most of the respondents in adoption were fear of taking risk while growing new sugarcane varieties soon after release, new varieties needed more inputs, increased rodent menace in trash mulching, occurrence of new pests and diseases and lack of labour to do ratoon management operations in time. In spite of these constraints, all the farmers favoured the continued adoption of advanced sugarcane technology. The study also helps to get a better understanding of the performance of scientific technologies in farmer's fields and the apprehensions of sugarcane growers. 
technological gap as well as yield gap in sugarcane that leads to reduced production and productivity (Rajula Shanthy and Subramanian, 2015). Sugarcane production can be sustained only if profitability can be ensured through reduction in cost of cultivation and improvement in productivity.

The technologies in sugarcane that can minimize the cost of cultivation with increased returns include wider row spacing, biofertilizers, bud chip settling transplanting, integrated nutrient management etc. (Rajula Shanthy, 2012).

The agricultural research system in the country has a strong technological back up suited for all regions. The sugarcane research stations and other research institutes concerned with sugarcane crop release new sugarcane varieties and related crop production and protection technologies. All these technologies have to reach the cane growers so as to realize an increase in cane productivity (Rajula Shanthy, 2010).

The sugar factories are getting converted into sugar complexes due to the increased use of byproducts like alcohol and co-generation that has become equally important to sugar. As a result, the seasonal industry turns into nonseasonal industry.

This requires a steady supply of cane to the factories and this can be made possible by increased adoption of sugarcane technologies and increased recovery percentage.

Keeping this in view, the present investigation attempted to know the profile of sugarcane farmers, their level of adoption related with the technology in sugarcane, to help to understand the advantages, field level problems in adoption and further to suggest ways to increase adoption of sugarcane technologies.

\section{Materials and Methods}

The study was conducted by using descriptive type of research design applying ex-post facto approach and the respondents were selected among growers cultivating sugarcane for a minimum of five years. The study focused on the adoption pattern of sugarcane technologies by registered sugarcane growers. Accordingly, it was decided to select Madras Sugars Ltd., (Subsidiary of Bannari Amman Sugars Ltd.) located in Vengur village, Thirukovilur taluk in Villupuram District, Tamil Nadu, which was recording moderate level of sugarcane yield. The average cane yield level recorded in the reserved area of the mill was $80 \mathrm{t} / \mathrm{ha}$ as against the state average yield of $100 \mathrm{t} / \mathrm{ha}$ and there is an urgent need to assess the feedback from farmers to fine tune the adoption pattern in sugarcane cultivation technologies and popularize it among other registered cane growers to increase the productivity of sugarcane.

The area of operation of the sugar mill spreads over the district of which Mugaiyur block was selected purposively as sugarcane is a major crop in this area and sugarcane is being grown for years and the farmers here are quite progressive in their approach striving towards betterment by all means. From the Mugaiyur block selected, four villages namely Pallichandali, Jambai, konganamur and Manalurpet were selected purposively due to more area under sugarcane crop. From the selected four villages, fifteen cane growers each were selected at random from each village. Thus the total sample size of the study was 60 registered sugarcane growers.

The particulars were collected using an interview schedule, the sociological appraisal was done through focus group discussions / observations, and yield data were recorded from the individual farms. The data collected 
were tabulated and analyzed using descriptive statistics comprising frequency analysis and simple percentage analysis.

\section{Results and Discussion}

The present study focused on the profile of farmers adopting sugarcane technologies, the adoption level, advantages in adoption and constraints involved in following the recommended sugarcane technologies.

\section{Demographic profile of sugarcane farmers adopting drip irrigation system}

Demographic profile of the respondents indicated that they were mostly middle aged (35-50 years: $48.33 \%)$ to old aged ( $>50$ years: $41.67 \%$ ) and literates with up to secondary education (73.33\%); Agriculture was the main occupation for almost all the respondent farmers $(98.33 \%)$ and $48.33 \%$ had up to 25 years of farming experience and $80 \%$ had over 10 years of experience in sugarcane farming; Majority of them (73.33\%) owned 2 4 acres of land. Over half of the respondents $(55 \%)$ were self-sufficient in implement possession while others either fully or partially depended on hiring. Crop rotation was followed by $66.67 \%$, paddy $(23.33 \%)$ and the rest opted for blackgram, maize, groundnut.

Over three-fourth $(78.33 \%)$ of the respondents owned livestock such as cows, buffaloes, draught animals and poultry for additional source of income, apart from their own use; Mass media channels used by the respondents were radio, television and newspaper; All the respondents possessed radio / television, and a great majority of them (97\%) watch/listen television / radio regularly. This indicated a deep penetration of radio and television in rural areas and television was the main entertainment for them. Regarding newspapers, it was observed that around $63.33 \%$ of respondents were regular subscribers of newspapers. Majority $(66.67 \%)$ of them had medium level of social participation as they were more into agriculture.

Source of information on improved agricultural practices was sugar mill staff $(83.33 \%)$, input dealers \& neighbours $(6.67 \%) \&$ other farmers $(10 \%)$. The number of ratoon crops taken up by the respondents were up to 2 (48.33\%), 3-4 (41.67\%), and more than $4(10 \%)$.

\section{Extent of adoption of sugarcane technologies by the respondent farmers}

Depending on the level of exposure to various sugarcane management practices and the necessity realized to reap a better crop, farmers have adopted the various recommended sugarcane technologies as listed in table 1.

Table 1 indicates that the technologies viz., ploughing using rotavator or cultivator, making ridges and furrows, use of new sugarcane varieties are adopted by all the respondents of the study. The varieties grown by the respondents include Co 86032, Co 0212, CoC 24 and PI 1110.

The normal spacing of $90 \mathrm{~cm}$ is being followed by the farmers. Wider row spacing has not come up in a big way in the study area; though its advantageous in several ways (Rajula Shanthy and Muthuswamy, 2012).

Basal application of phosphorous in the recommended level is being followed by all the respondents either as single super phospahate or diammonium phosphate. This results in better root formation. Many farmers apply phosphorous fertilizers even without proper knowledge about its function in root development. 
All the farmers use a set rate of 75,000 two budded setts per hectare as recommended and over three-fourth $(78.33 \%)$ used two budded setts. They also apply organic manure to the amount to which it is available. The average of the sample are $14 \mathrm{t} / \mathrm{ha}$ of FYM or 12 tons of organic manure/ha or 10 tons of pressmud/ha.

Atrazine is applied as pre-emergence weedicide within five days after planting by $80 \%$ of the respondents. Also, hand weeding is followed by $98.33 \%$ of the farmers in the study sample.

Most of the farmers have awareness of drip irrigation but they have not installed because they depend on ground water sources and sometimes get water through canals also. They are of the opinion that water which comes from dams through canals would increase the yield. Hardly $12 \%$ have adopted drip irrigation. Srivasatava et al, 2007 and Gupta et al., 2009 have reiterated the importance of adopting micro irrigation in a long duration crop like sugarcane.

Farmers have realized the importance of application of bio-fertilizers as evidenced by $53.33 \%$ of the respondents adopting the technology. They get $6-8 \mathrm{t} / \mathrm{ha}$ additional cane yield in response to bio-fertilizer application. Nitrogen fixers like Azospirillum and phosphatic biofertilizer Phosphobacteria are applied at $30^{\text {th }}$ and $60^{\text {th }}$ days of planting. Urea and potash are applied during first and second top dressing at 45 and 90 days after planting by almost half of the respondents.

Earthing up and gap filling in ratoon crop are being followed by over $75 \%$ of the respondents. Earthing up is done twice during which top dressing is given.

Detrashing is done by $75 \%$ of the respondents. The dried leaves are being removed during $5^{\text {th }}$ month by all of them and in $7^{\text {th }}$ month by only very few farmers. In most of the cases the dried trash is left in the field for composting. Propping is not done as they do not have the need for this operation and it is expensive as well.

Early shoot borer is widely prevalent in the study area and farmers use chemical control for combating the pest. Nearly $76.6 \%$ of the respondents resorted to chemical control. Use of pheromone traps for control of borer pests is yet to be popularized. Hardly $22 \%$ of the respondents use pheromone traps and that too for managing internode borer.

As drought is quite prevalent in the study area, farmers resort to various drought management operations. Sett treatment with bavistin is being adopted by $25 \%$ of the respondents. They just dip the setts in fungicide to control the sett borne infections. The other practices like spraying urea + potash solution, ferrous sulphate for iron chlorosis are being adopted by less respondents. It is applied as and when need arises. Ratoon management operations like off barring and root pruning are being followed by around $75 \%$ of the respondents. Stubble shaving is followed by $78 \%$ of the respondents. This results in development of healthy root system for the ratoon crop resulting in increased ratoon yield. Farmers use polybag seedlings or quartering for gap filling in ratoon crop.

\section{Advantages in adoption of new sugarcane technologies}

Selection of an appropriate sugarcane variety suited to the location is the first step towards reaping a better crop. Added to this, adoption of recent technologies recommended by research institutes also help to boost the productivity of sugarcane crop. 
Table.1 Adoption level of sugarcane technologies by respondents $(\mathrm{N}=60)$

\begin{tabular}{|c|c|c|}
\hline Technology & $\begin{array}{l}\text { No. of } \\
\text { respondents }\end{array}$ & Percentage \\
\hline $\begin{array}{l}\text { New varieties (Co 0212, CoC 24, PI 1110) \& Co } \\
86032\end{array}$ & 60 & 100 \\
\hline \multicolumn{3}{|l|}{ Land Preparation } \\
\hline a. Country Plough (Two times) & 35 & 58.33 \\
\hline b. Rotavator / Cultivator Ploughing & 60 & 100 \\
\hline c. Ridges and Furrows making & 60 & 100 \\
\hline \multicolumn{3}{|l|}{ Basal Application: } \\
\hline a. FYM (14 t/ha)/ pressmud (10 t/ha) & 57 & 95.00 \\
\hline b. SSP & 18 & 30.00 \\
\hline c. DAP & 42 & 70.00 \\
\hline \multicolumn{3}{|l|}{ Setts and Sett Treatment } \\
\hline a. Two Budded & 47 & 78.33 \\
\hline b. Three budded & 13 & 21.67 \\
\hline c. Bavistin + Urea + Lime treatment & 14 & 23.33 \\
\hline \multicolumn{3}{|l|}{ Weeding } \\
\hline a. Pre or Post emergence herbicide & 48 & 80.00 \\
\hline b. Hand weeding & 59 & 98.33 \\
\hline Installation of Drip Irrigation & 7 & 11.67 \\
\hline Application of Bio-fertilizers & 32 & 53.33 \\
\hline Release of Trichogramma for INB & 12 & 20.00 \\
\hline Pheromone traps for borers & 19 & 31.67 \\
\hline Application of $\mathrm{Fe}_{2} \mathrm{SO}_{4}$ to control iron deficiency & 11 & 18.33 \\
\hline \multicolumn{3}{|l|}{ Top dressing } \\
\hline a. Top dressing -I & 55 & 91.67 \\
\hline b. Top dressing - II & 45 & 75.00 \\
\hline Detrashing & 45 & 75 \\
\hline Propping & 1 & 1.66 \\
\hline \multicolumn{3}{|l|}{ Drought Management } \\
\hline a. Sett treatment with lime & 15 & 25.00 \\
\hline b. Urea + Potash spray & 3 & 5.00 \\
\hline c. Additional potash application & 15 & 25.00 \\
\hline d. Trash mulching & 52 & 86.67 \\
\hline \multicolumn{3}{|l|}{ Ratoon crop management } \\
\hline Stubble shaving & 47 & 78.33 \\
\hline Off-barring & 44 & 73.33 \\
\hline Gap filling & 47 & 78.33 \\
\hline
\end{tabular}


Table.2 Constraints in adoption of sugarcane technologies

\begin{tabular}{|l|l|l|c|}
\hline \multicolumn{1}{|c|}{ Constraints } & No. & $\%$ & Rank \\
\hline New Varieties & 38 & 63.33 & I \\
\hline Fear of tasking risk & 37 & 61.67 & II \\
\hline Need more inputs \& thereby high cost of cultivation & 31 & 51.67 & III \\
\hline Lack of awareness about new varieties & 30 & 50.00 & IV \\
\hline Lack of conviction & 29 & 48.33 & V \\
\hline Sugar mills may not prefer & 29 & 48.33 & V \\
\hline High transport cost & 11 & 18.33 & VI \\
\hline Non- availability of setts in time & 05 & 8.33 & VII \\
\hline $\begin{array}{l}\text { Affected by more pests and diseases than the existing } \\
\text { variety }\end{array}$ & 02 & 3.33 & VIII \\
\hline High flowering percentage & 02 & 3.33 & IX \\
\hline Not suited to local conditions & & & \\
\hline Crop production technologies & 46 & 76.67 & I \\
\hline Trash mulching increases rodent problem & 36 & 60.00 & II \\
\hline Complicated nature of trash mulching & 30 & 50.00 & III \\
\hline Propping involves unnecessary expenses & 28 & 46.67 & IV \\
\hline Non-availability of labour for detrashing & 24 & 40.00 & V \\
\hline High cost of organic manures & 18 & 30.00 & VI \\
\hline Non-availability of in organic fertilizers in time & 17 & 28.33 & VII \\
\hline Non availability of bio-fertilizers in time & 11 & 18.33 & VIII \\
\hline Non-availability of organic manures & & & \\
\hline Crop protection technologies & 51 & 85.00 & I \\
\hline Incidence of new pests and diseases & 48 & 80.00 & II \\
\hline No proper mgt measures for new pests/diseases & 46 & 76.67 & III \\
\hline Lack of adequate knowledge about pheromone traps & 38 & 63.33 & IV \\
\hline Non-availability of Trichogramma egg cards in time & 36 & 60.00 & V \\
\hline $\begin{array}{l}\text { Lack of knowledge about correct management } \\
\text { measures }\end{array}$ & 35 & 58.33 & VI \\
\hline Non-availability of pheromone traps and lures & 22 & 36.67 & VII \\
\hline $\begin{array}{l}\text { Non-availability of plant protection chemicals in } \\
\text { time }\end{array}$ & & & \\
\hline Ratoon management & 41 & 68.33 & I \\
\hline Lack of labour to do ratoon mgt operations in time & 30 & 50.00 & II \\
\hline High cost of stubble shaving \& off-barring & 29 & 48.33 & III \\
\hline Poor yield in plant crop & 25 & 41.67 & IV \\
\hline Piece-meal harvest leads to poor ratoon crop & 09 & 15.00 & VI \\
\hline Lack of knowledge about proper gap filling & & & \\
\hline Poor ratooning capacity of the variety & & & \\
\hline
\end{tabular}


Table.3 Suggestions to increase the adoption of sugarcane technologies

\begin{tabular}{|l|c|c|c|c|}
\hline \multirow{2}{*}{ Suggestions } & \multicolumn{3}{|c|}{$\begin{array}{c}\text { Highly } \\
\text { Necessary }\end{array}$} & \multicolumn{2}{c|}{ Necessary } \\
\cline { 2 - 5 } & No. & $(\%)$ & No. & $(\%)$ \\
\hline Pre-season campaigns & 45 & 75 & 15 & 25 \\
\hline Distribution of printed literature & 35 & 58.3 & 25 & 41.6 \\
\hline More field days to create awareness & 37 & 61.6 & 23 & 38.3 \\
\hline Demonstrations in farmers fields & 40 & 66.6 & 20 & 33.3 \\
\hline Financial support & 35 & 58.3 & 25 & 41.6 \\
\hline Providing subsidies for the technology & 28 & 46.6 & 32 & 53.3 \\
\hline Training program for farmers & 40 & 66.6 & 20 & 33.3 \\
\hline Study tour & 18 & 30 & 42 & 70 \\
\hline $\begin{array}{l}\text { More efforts by the cane department of } \\
\text { the sugar mill in spreading the }\end{array}$ & 40 & 66.6 & 20 & 33.3 \\
technology & & & & \\
\hline
\end{tabular}

The farmers in the study area were found to be medium to high in their level of adoption of various sugarcane technologies. The advantages as reported by the respondents include:

Use of adequate sett material of appropriate age results in better germination resulting in optimum plant population.

Basal application of organic manure / farm yard manure / pressmud increases the fertility of soil.

Adopting integrated approach for pest and diseases management results in reduced yield loss.

Adoption of scientific crop management practices has increased the cane yield, thereby reducing the yield gap between the potential and actual yield.

Ratoon management practices viz., stubble shaving and off barring is a must to increase the cane yield of ratoon crop.

Integrated nutrient management leads to better crop stand thereby higher yield

Drip irrigation saves 40-45\% irrigation water apart from giving better cane yield.
Constraints faced by farmers in adopting sugarcane technologies

Every year, new technologies are introduced by research stations to the farmers. These technologies are introduced after conducting field demonstration trials. However, when the farmers adopt the technologies in a large scale, they face a lot of problems which they may or may not realize. Any attempt made by the researchers to eliminate these constraints will result in increased adoption of technologies of recommended package of practices which will ultimately lead to increase the production, productivity and also improve the sugar recovery $\%$. Thus farmers will get monetary benefits with reduction in cost of production.

The constraints faced by the respondent farmers in adopting sugarcane technologies are detailed in table 2 and discussed in their order of importance.

\section{Constraints in adopting New Varieties}

Among the constraints expressed by the respondents in adopting new sugarcane varieties, high cost of inputs was of major 
concern as expressed by $62 \%$ of the respondents. The high cost of inputs like fertilizers, pesticides etc. hinders adoption of the technology by resource poor farmers. Farmers were also not ready to take any risk of reduction in cane yield or any other adversities. Often times, they were not aware of the existence of new sugarcane varieties and even if aware they lacked conviction as expressed by $50 \%$ of the respondents. High transport cost was another factor hindering them to take planting material from far off places. Though new varieties are released, it takes quite a considerable time for the planting material to be available for general cultivation. Though the farmers may be willing to adopt the new varieties, nonavailability of adequate quantity of sett materials prevent them from growing new sugarcane varieties. Even if it is available, they had to pay higher cost for the plating material. Co 86032 is the variety grown by almost all the respondents.

\section{Constraints in adopting crop production technologies}

Trash mulching is being popularized in the study area by the sugar mill and department officials. But the farmers foresee rodent problem to be high when they adopt trash mulching. Detrashing and propping are not followed widely as these practices involve labour which is costly. Detrashing is done to a certain level by the family labour itself to feed their own cattle. High cost of organic manure is a constraint as expressed by $40 \%$ of the respondents and the availability is in question. Labour has become a scarce commodity. Availability of labour during peak seasons is a major hindrance for adoption and the cost of available labour also is alarming. Few farmers in the study area adopt drip fertigation. However, they have expressed the nonavailability of water soluble fertilizers for use in drip fertigation.

\section{Constraints in adopting crop protection technologies}

For the control of borers, farmers have started adopting pheromone traps. Lack of adequate knowledge about the correct use of pheromone traps and non-availability of pheromone lures in time is a major constraint for widespread adoption of the technology. Non-availability of the exact chemical pesticides at the right time in the village is also a major concern. Also farmers have expressed their concern about the incidence of new pests now and then.

\section{Constraints in adopting ratoon management measures}

Ratoon crop has to be given equal importance so as to get a remunerative return from sugarcane cultivation. Since cost of cultivation is comparatively lesser in ratoon than plant crop, it can be made profitable. The respondents reported lack of knowledge of practices like gap filling and high cost involved as major constraints. The other constraints in their order of importance were poor yield in plant crop (48.33\%), piece meal harvest of the crop leading to poor ratoon $(42 \%)$, and poor ratooning capacity of the variety cultivated $(15 \%)$.

Constraints in adopting harvest management practices: Constraints in sugarcane cultivation continue even after harvest of the crop. Availability of cutting orders in time (97\%) is the major constraint when it is a normal year. Farmers have to wait even when the crop is 14 months or beyond. Availability of transport of the harvested cane in time $(95 \%)$ is also a major concern as it leads to weight reduction. Quick harvest of burnt cane field $(83 \%)$ is seen as it hinders cutting order for green cane. Availability of labour in time (78\%) is a hindrance in many places and is expensive also. Payment of cane 
price at least within 15 days after harvest as reported by $57 \%$ would be of use to them.

Suggestions to increase the adoption of technologies

Due to the advancement in scientific approach towards agriculture, many new technologies are available for adoption. It is not the dearth of technology that haunts Indian agriculture today, but the non availability of adequate knowledge about the technologies to the intended clients. Adequate technical support is needed to increase the rate of adoption. The suggestions as indicated by sugarcane growers are given in table 3 .

Awareness campaigns prior to planting helps the farmers to be well equipped with the information on latest sugarcane technologies.

Nearly $67 \%$ of the respondents suggested that more efforts are needed by the cane officials in disseminating the latest sugarcane technologies. Farmer participatory trials and demonstrations in the village level were also perceived to help in spreading the technology at a faster pace. Study tours to nearby model farms in the research stations or farmers' fields were suggested as necessary by $70 \%$ of the respondents.

Training programs, off - farm and on- farm help to create awareness about the latest technology and provides first-hand information to the farmers. This was suggested by $66.6 \%$ of the respondents.

Field Days organized in the villages help experience sharing among the farmers. Success stories in this regard serve as a motivation for other farmers as well.

In conclusion the survey among sugarcane growers have revealed the existence of wide technological gap as well as yield gap in sugarcane that leads to reduced production and productivity (SezhianBabu, 1990; Gupta, 2009; RajulaShanthy and Ramanjaneyalu, 2016). Even proven technologies like settling transplanting technology, wider row spacing, drip irrigation etc. are not readily and completely accepted by the cane growers; rather they take their own time to adopt it. However, farmers have started realizing the importance of cultivating sugarcane crop in a more scientific way and this calls for continued technical guidance by the extension staff concerned.

\section{Acknowledgements}

The authors thank the cane officials of the sugar factories concerned for their support and cane growers who spared their time to be the respondents for this study.

\section{References}

Gupta.C., D. Esther Shekinah and Rakkiyappan P. 2009. Designing irrigation system and scheduling of irrigation in sugarcane (In: T.Rajula Shanthy and N.Vijayan Nair (Ed). Technologies to improve sugarcane productivity SBI, Coimbatore).

Panghal, S.S., 2010. Cane production mechanization - A solution for labour problems. Indian Sugar. 45: 27-32.

Rajula Shanthy, T. 2010. Gender perspectives for sustaining sugarcane based cropping system. Indian Research Journal of Extension Education. 10(1):112-116.

Rajula Shanthy, T. 2012. Strategies for effective dissemination of appropriate technologies to sugarcane growers in India. Sugar Tech 13(4): 354-359.

Rajula Shanthy, T., and Muthuswamy, G.R. 2012. Wider row spacing in sugarcane: A socioeconomic performance analysis. SugarTech 14(2):126-133.

Rajula Shanthy, T., and Subramanian, R. 
2015. Farmers' perspective on integrated nutrient management in sugarcane. Indian Research Journal of Extension Education 15(1):100-106.

Rajula Shanthy, T., and Ramanjaneyalu, S. 2016. Socioeconomic performance analysis of sugarcane cultivation under sustainable sugarcane initiative method. Indian Research Journal of Extension Education 14(3):93-98.

Rajula Shanthy, T., K. Manivel and Saravanan, L. 2021. Adoption of drip irrigation: A performance analysis. Indian Research Journal of Extension Education. 21(1): 1-6.
Sezhianbabu, S., 1990. Information source utilization, knowledge and extent of adoption of sugarcane technology by registered cane growers. Unpub. M.Sc. (Ag.) Thesis., TNAU, Coimbatore, India.

Srivastava, R.N., S.B.Singh and Sudama Singh. 2007. Water management in sugarcane. In sugarcane crop production and improvement (Eds. S.B.Singh, G.P.Rao, S.Solomon and P.Gopalasundaram). PP.511-530. Studium Press LLC, Texas, USA.

\section{How to cite this article:}

Jitendra Kumar Chauhan, T. Rajula Shanthy and Senthamil. 2021. Adoption of Technologies in Sugarcane - A Performance Analysis. Int.J.Curr.Microbiol.App.Sci. 10(01): 1892-1901. doi: https://doi.org/10.20546/ijcmas.2021.1001.221 